\title{
Carica papaya leaf ethanol extract effect on milk volume, $\beta$-casein gene (Csn2) expression, $\beta$-casein levels, and milk total protein levels
}

\author{
Yanti Herawati1,2* Umi Kalsum³ ${ }^{3}$ I Wayan Arsana ${ }^{4}$, Lelly Yuniarti5 ${ }^{5}$ Teguh Wahju Sardjono ${ }^{6}$ \\ 1 Midwifery Master Program, STIKes Dharma Husada, Bandung, Indonesia \\ Doctoral Program, Faculty of Medicine, Universitas Brawijaya, Malang, Indonesia \\ 3 Department of Pharmacology, Faculty of Medicine, Universitas Brawijaya, Malang, Indonesia \\ 4 Department of Obstetrics and Gynecology, Saiful Anwar Hospital, Faculty of Medicine, Universitas Brawijaya, Malang, Indonesia \\ 5 Department of Biochemistry, Faculty of Medicine, Universitas Islam Bandung, Indonesia \\ 6 Department of Parasitology, Faculty of Medicine, Universitas Brawijaya, Malang, Indonesia
}

\begin{abstract}
The phytochemical compounds contained in papaya leaves are known to have a galactopoietic effect. This study aims to analyze the effect of ethanol extract of Carica papaya leaves on $\beta$-casein gene expression, $\beta$ casein levels, total protein, and milk volume. This in vivo was an experimental study including a posttest control group that was conducted on one control group and three treatment groups. Each group consisted of six lactating rats. The control group rats were given ordinary food, while the treatment group rats, D1, D2, and D3, were given ethanol extract of Carica papaya leaves with the dose of $0.95 \mathrm{mg}, 1.9 \mathrm{mg}$, and $3.8 \mathrm{mg} / 200 \mathrm{~g}$ Body weight (BW)/ day, respectively, from day 1 to day 13 of lactation. On day 14, all of the rats were sacrificed. Breastmilk volume taken from all breasts of lactating rats was measured individually in milliliters, $\beta$-casein gene expressions in the mammary tissues were measured using reverse transcription polymerase chain reaction (RT-PCR), while serum $\beta$-casein levels were measured using ELISA, and total protein was measured using bicinchoninic acid (BCA) protein assay. Statistical analysis was carried out using one-way ANOVA, Tukey test, and Games-Howell test at $95 \%$ confidence level. Milk volume, $\beta$-casein gene expression, $\beta$-casein levels, and total protein levels of all treatment rat groups were significantly higher than the control group $(p<0.05)$. The increases of all parameters were consistent; the most effective dose was $1.9 \mathrm{mg} / 200 \mathrm{~g}$ BW. Carica papaya leaf ethanol extract can increase milk volume, $\beta$-casein gene (Csn2) expression, $\beta$-casein levels, and total protein levels.
\end{abstract}

\section{Keywords:}

Carica papaya leaves, Milk volume, Csn2 expression, $\beta$-Casein level, Total protein, Lactating Rat

\section{INTRODUCTION}

Breast milk is the main nutrient for babies in the first 6 months of life. It is a specific biofluid with high variations in its composition, namely, nutritional, and bioactive components, which play an important role in the process of infant growth and development. Babies born to mothers with good nutritional status have adequate nutrition reserves at birth; however, after birth, nutritional fulfillment is completely dependent on breast milk ${ }^{1-3}$.

The main macronutrient composition in breast milk includes lactose, oligosaccharides, fat (triglycerides, phospholipid cholesterol, and steroid hormones), protein (casein, $\alpha$-lactalbumin, lactoferrin, secretory IgA, and lysozyme), and minerals (sodium, potassium, chloride, calcium, magnesium, and phosphate $)^{4}$. Approximately $0.9 \%$ of the protein components of breast milk consists of the casein, albumin, $\alpha$-lactalbumin, $\beta$-lactoglobulin, immunoglobulin, lactoferrin, and glycoprotein groups ${ }^{5-6}$. Most of these components of breast milk are synthesized by the alveolar epithelial cells (lactocytes) in the mammary glands ${ }^{7}$.

\section{*Corresponding author:}

*Yanti Herawati Email: yantiherawati@stikesdhb.ac.id 
The production of breast milk in the mammary epithelial cells is regulated by several factors, such as the hormone system and growth factors. Prolactin and glucocorticoids are lactogenic hormones that play a role in the production of breast milk. The amount of these hormones will increase after delivery. Epidermal growth factor together with prolactin regulates alveolar development and milk protein expression ${ }^{7}$.

Protein in breast milk controls the growth process of babies. It is a source of essential amino acids and increases the absorption and digestion of nutrients by increasing the solubility and availability of nutrients. These mechanisms include $\beta$-casein and $\alpha$-lactalbumin, which support the absorption of calcium, zinc, and iron owing to their active site that can bind to these minerals. For example, in infants, the uptake of iron does not occur in the intestine. Iron which has been chelated with lactoferrin will be released through the lactoferrin receptor.

Casein is the main specific protein in breast milk, consisting of as1-, $\alpha$ s2-, $\beta-$, and $\kappa$ - casein subtypes. $\beta$-casein is the main specific type of protein in breast milk produced by most mammals and during lactation ${ }^{7}$. $\beta$-casein contains many essential amino acids and calcium $^{7,9}$.

The importance of breast milk for infant growth and development encourages mothers who experience a shortage or decrease in milk production to use traditional plants to increase milk production ${ }^{10}$. Medicines or herbal plants that can stimulate breast milk production are known as galactagogues. Research shows that herbal galactagogue administration in the first 1-2 weeks of birth is effective in increasing serum prolactin and oxytocin levels in nursing mothers ${ }^{3,11}$.

Galactagogue is a synthetic material or plant molecule that is used to induce, maintain, and increase breast milk production ${ }^{12-13}$. Jayadeepa et al. identified phytochemical compounds in plants or fruits that are commonly used as galactagogues ${ }^{14}$. Tabares et al. classified six common herbal galactagogues that have been used, such as Fenugreek (Trigonella graecum foenum), Fennel (Foeniculum vulgare), Anise (Pimpinella anisum), Goats' rue (Galega officinalis), Asparagus (Asparagus racemosus), and Milk thistle (Sylibum marianum); all of these plants have a dopamine antagonist effect that can bind to dopamine receptor and induce prl gene expression, blood level prl increases, milk protein synthesis rate increases, and MEC proliferation increases ${ }^{13,15-17}$.

Carica papaya Linn. is known as papaya in Indonesia, Croatia, Germany, and Italy and is also known as pawpaw in Australia ${ }^{18}$. It originated from the lowlands of Central, North, and East America ${ }^{19}$. Papaya is a plant in which almost all parts, including leaves, sap, seeds, roots, stems, and fruit, can be used ${ }^{20}$. The active ingredients found in papaya leaves include alkaloids, carpaine, dehydrocarpaine, flavonols, tannins, nicotine, and prunasin (cyanogenic glycosides) ${ }^{18,21}$. In addition, it also contains minerals in the form of calcium, potassium, magnesium, iron, copper, zinc, and manganese, as well as vitamins in the form of thiamin, riboflavin, niacin, ascorbic acid, and $\alpha$-tocopherol ${ }^{20}$.

Papaya leaves contain alkaloids, phenols, flavonoids, and amino acids (including cysteine, homocysteine, glutamic acid, and phenylalanine) $)^{22}$. It also contains saponins, lycopene, tocopherols, as well as several vitamins $(\mathrm{A}, \mathrm{B}, \mathrm{B} 2, \mathrm{~B} 6, \mathrm{~B} 9, \mathrm{C})$ and minerals $(\mathrm{S}$, $\mathrm{K}, \mathrm{P}, \mathrm{Mg}, \mathrm{I}, \mathrm{Ca})^{23}$. Cysteine is one of the essential amino acids that is highly conserved and plays a role in the cellular signaling process and phosphorylation reactions ${ }^{24}$.

Glutamic acid (or often called glutamate) is an amino acid that plays an important role as an energy substrate in intestinal epithelial cells and a precursor to the immune system, especially in the growth phase. In addition, glutamate also acts as a glutathione precursor, which is an antioxidant compound that plays a role in preventing cell damage and allergic reaction ${ }^{25}$. Phenylalanine is one type of essential amino acid that is needed in high amounts in pregnant women to help in protein synthesis $^{1,26}$

In several studies, the phytochemical compounds contained in papaya leaves are known to have a galactopoietic effect. Among them, alkaloids can help in the secretion of breast milk. Isoflavones can help to increase the protein, fat, and lactose components in breast milk. Polyphenols can increase the production of milk protein. Tannins play a role in improving protein digestion $^{27}$. However, the mechanism of the effect of papaya leaf extract as a whole on increasing the quantity and quality of breast milk has not been studied in depth. This study aims to determine the galactagogue mechanism of the effect of papaya leaf ethanol extract on milk volume, $\beta$-casein $(\mathrm{Csn} 2)$ gene expression, $\beta$-casein levels, and total protein content.

\section{MATERIALS AND METHODS}

\subsection{Study design and subjects}

This in vivo was an experimental laboratory study with a posttest only control group that was carried out on lactating rats. Female Wistar rats were obtained from the laboratory animal breeding division of PT Bio Farma, Bandung, Indonesia. Acclimatization of the rats was carried out for 1 week to condition the mice in a laboratory atmosphere. Rats were given food and drink as needed based on the standard laboratory feed. Rats are placed at room temperature $\left(20-25^{\circ} \mathrm{C}\right)$ in a clean cage (length, $70 \mathrm{~cm}$; width, $50 \mathrm{~cm}$; height, $55 \mathrm{~cm}$ ), with a maximum capacity of six rats. The research was carried out from September 2019 to September 2020 and was approved by the Research Ethics Committee of Padjadjaran University, Bandung (No. 1340/UN6.KEP/EC/2019). 


\subsection{Experimental animals}

A total of 24 female Wistar rats (Rattus norvegicus) aged 12-14 weeks with body weight ranged from 200-225 grams were the subjects in this study. The rats were simultaneously and fairly mated (1:1) within one night, after estrous synchronization by utilizing the natural phenomena, namely, Lee-Boot, Pheromone and Whitten effect, so that they would have the same lactation period ${ }^{28}$. The rats then were divided into four groups and each group consisted of six rats each. The control group was receiving ordinary foods while three treatment groups, D1, D2, and D3 were treated with ethanol extract of Carica papaya leaves with the doses of $0.95 \mathrm{mg} / 200$ $\mathrm{g} \mathrm{BW} /$ day, $1.9 \mathrm{mg} / 200 \mathrm{~g} \mathrm{BW} /$ day, and $3.8 \mathrm{mg} / 200 \mathrm{~g}$ $\mathrm{BW} /$ day, respectively, from day 1 to day 13 postdelivery. The calculation of the dose used was based on the results of the research by Kharisma et al. ${ }^{29}$. On day 14 postdelivery, the rats were anesthetized. The cardiac puncture blood samples were taken for measurement of $\beta$-casein levels using ELISA. The breast milk was taken individually by massaging the mammary area from each rat's breasts to measure the volume in milliliters. We took the first two samples of the right and left breasts of each rat for the measurement of $\beta$-casein gene expression using real-time PCR.

\subsection{Ethanol extract of Carica papaya leaves}

The ethanol extract of papaya leaf was made using the reflux method proposed by Zhang et al. ${ }^{30}$. A total of $3 \mathrm{~kg}$ of papaya leaf simplicia was obtained from the Manoko (Lembang), West Java. The plantation was dissolved in $1,000 \mathrm{ml}$ of $95 \%$ ethanol at $50^{\circ} \mathrm{C}$ for $24 \mathrm{~h}$. The solution was then filtered. The resulting filtrate was evaporated using a rotary evaporator, and $118 \mathrm{~g}$ of concentrated extract was obtained. Papaya leaf extract was given orally on days 1 to 13 .

\subsection{Measurement of milk volume}

Breast milk was taken on day 14 from all breasts of lactating rats and measured in $\mu$ l. Milk was taken by massaging the mammary area using the same examiner's hand for 1 hour. The milk coming out was immediately taken using a $1-\mathrm{cc}$ syringe and put into a 2 $\mathrm{mL}$ tube.

\subsection{Measurement of $\beta$-casein $(\operatorname{Csn} 2)$ gene expression}

$\beta$-casein (Csn2) gene expression was measured using a real-time PCR by comparing the mRNA expression of the $\beta$-casein gene $(\mathrm{Csn} 2)$ with the housekeeping gene GAPDH. In this study, the PCR cycle along with time and temperature was the same for all genes examined. The primary sequence of the Csn2 gene is forward 5'-AAACATCCAGCCTATTGCTC-3' and reverse $\beta$-casein $5^{\prime}$-CATCTGTTTGTGCTTGGGAA- $3^{\prime}$. The primary sequence for GAPDH is forward GAPDH 5'-TGCCAGCCTCGTCTCATAG-3' and reverse GAPDH 5'ACTGTGCCGTTGAACTTGC-3'. Reverse transcripttion was done at $45^{\circ} \mathrm{C}$ for $10 \mathrm{~min}$. Initial activation (holding stage) was done at $95^{\circ} \mathrm{C}$ for $2 \mathrm{~min}$ and denaturation at $95^{\circ} \mathrm{C}$ for $5 \mathrm{~s}$. Annealing $\beta$-casein was done at $54^{\circ} \mathrm{C}$ for $20 \mathrm{~s}$ and $\mathrm{GAPDH}$ at $57^{\circ} \mathrm{C}$ for $20 \mathrm{~s}$, followed by a melt curve at a temperature of $60^{\circ} \mathrm{C}-95^{\circ} \mathrm{C}$. The level of gene expression was calculated according to the $2^{-\Delta \Delta \mathrm{CT}}$ method.

\subsection{Measurement of $\beta$-casein levels}

The $\beta$-casein level of rat milk was measured using ELISA. The sample used was $0.5 \mu \mathrm{l}$ of milk from lactating rats on the 14th day. The sample volume and standard for $\beta$-casein ELISA was $50 \mu$, which composed of $0.5 \mu \mathrm{l}$ sample and $49.5 \mu \mathrm{l}$ buffer with $100 \times$ dilution (optimization result). The absorbance was detected in 5 $\min$ at $450 \mathrm{~nm}$. Then the wavelength was set to $540 \mathrm{~nm}$ or $570 \mathrm{~nm}$ and the absorbance was subtracted with the absorbance at the wavelength of $450 \mathrm{~nm}$. $\beta$-casein levels were mea-sured using the $\beta$-casein ELISA kit (MyBioSource MBS916332).

\subsection{Measurement of total protein levels}

Total protein levels of milk were calculated using the BCA protein assay method. Samples were obtained from $25 \mu \mathrm{l}$ of mother's milk from lactating rats on day 14. Bovine serum albumin preparation was carried out first, and then protein content measurement was carried out based on the BCA protein assay kit method (Thermo 23227). The results were read at an absorbance of $562 \mathrm{~nm}$ using the TECAN Infinite M200 PRO Multimode reader. The work was done in duplicate.

\subsection{Statistical analysis}

The statistical methods in this study include Shapiro-Wilk, one-way ANOVA, Tukey test, GamesHowell test, and linear regression at the $95 \%$ confidence level $(p \leq 0.05)$. The program used was SPSS Ver. $25^{31}$.

\section{RESULTS}

\subsection{The effect of papaya leaf ethanol extract on milk volume}

Papaya leaf ethanol extract also influenced milk volume. As shown in Figure 1, the milk volume in lactating mice was $200 \mu \mathrm{l} / \mathrm{ml}$. The administration of papaya extract increased the milk volume to $274.2,386.7$, and $297.1 \mu 1 / \mathrm{ml}$ on D1, D2, and D3 respectively. The 


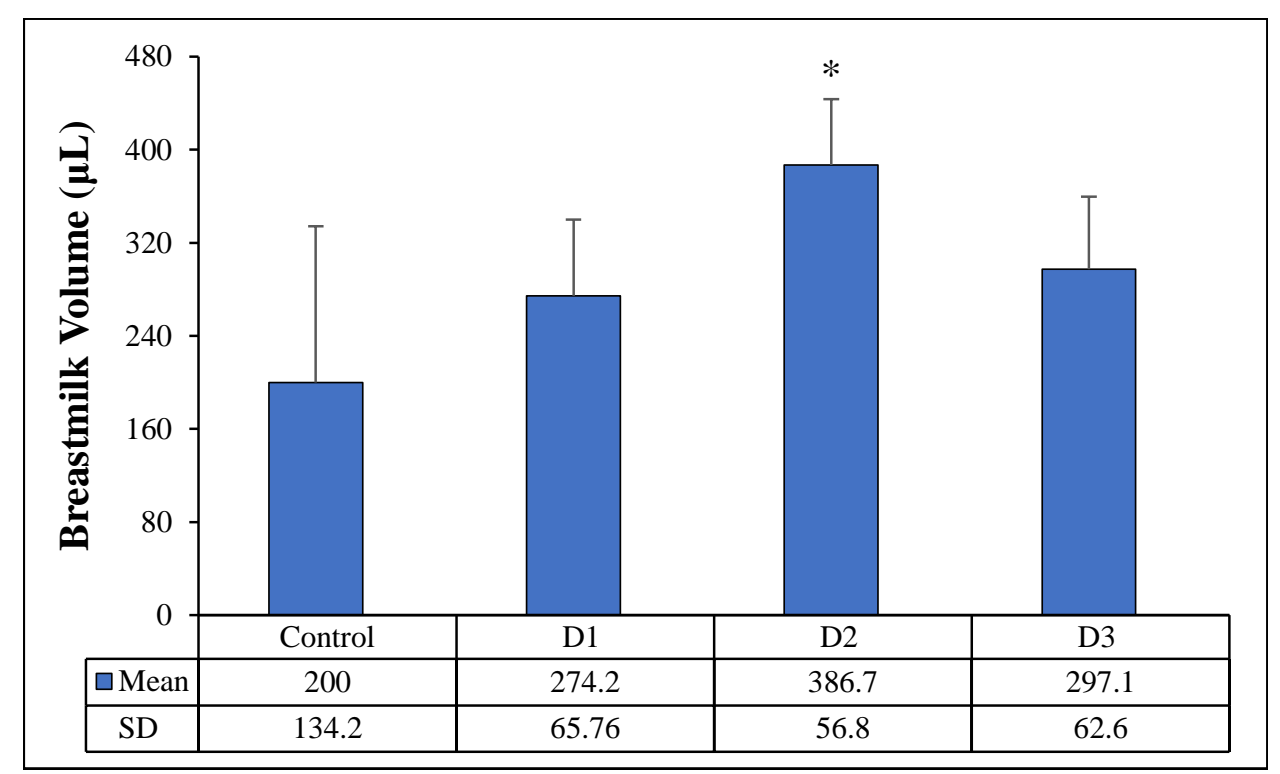

Figure 1. Effect of papaya leaf ethanol extracts on breast milk volume. D1, dose of $0.95 \mathrm{mg} / 200 \mathrm{~g} \mathrm{BW} / \mathrm{day}$; D2, dose of $1.9 \mathrm{mg} / 200 \mathrm{~g} \mathrm{BW} / \mathrm{day}$; D3, dose of $3.8 \mathrm{mg} / 200 \mathrm{~g} \mathrm{BW} /$ day. The data are presented as mean \pm standard deviations. * $p<0.05$ indicated a significant difference in treatment groups compared to the control group based on Tukey's HSD test.

Table 1. Results of simple linear regression analysis. ${ }^{*} p<0.05$ indicated a significant difference on papaya leaf ethanol extract administration against a volume of breast milk with linear regression equation $\mathrm{y}=3.762 \mathrm{x}+200.995$.

\begin{tabular}{lcclc}
\hline Variable & Coeff. Regression (B) & t cal & Sig.t & R Square \\
\hline Constant & 200.995 & 5.449 & 0.000 & $0.006^{*}$ \\
Dose of papaya leaf extract & 3.762 & 3.021 & 0.293 \\
\hline
\end{tabular}

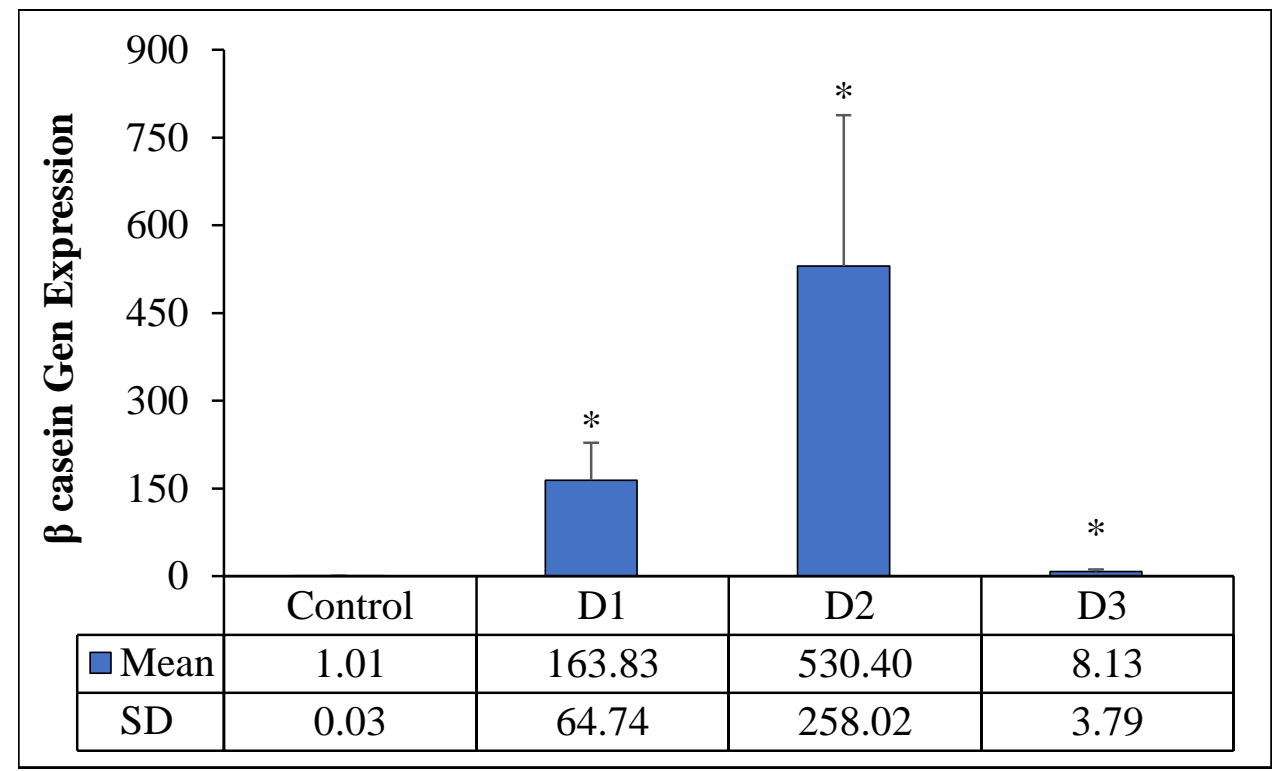

Figure 2. Effect of papaya leaf ethanol extracts in the $\beta$-casein (csn2) gene expression. D1, dose of $0.95 \mathrm{mg} / 200 \mathrm{~g}$ BW/day; D2, dose of $1.9 \mathrm{mg} / 200 \mathrm{~g} \mathrm{BW} /$ day; D3, dose of $3.8 \mathrm{mg} / 200 \mathrm{~g} \mathrm{BW} /$ day. The data are presented as mean \pm standard deviations. ${ }^{*} p<0.05$ indicated a significant difference in treatment groups compared to the control group based on Tukey's HSD test.

one-way ANOVA test results showed a significant difference in the mean volume of milk for the four groups of the observation sample $(p<0.000)$. Tukey's test showed that a dose of $1.9 \mathrm{mg} / 200 \mathrm{gr}$ BW/day was the highest dose to increase the volume of milk in lactating rats. Based on the $p$-value, the administration of D1 and D3 did not show a significant difference with the control group, while

\section{D2 showed a significant difference.}

Regression analysis was carried out to assess the relationship between the concentration of papaya leaf ethanol extract and the volume of breast milk. Table 1 presents the linear regression results. With each addition of one dose of papaya leaf extract, the volume of breast milk will increase by $3.762 \mathrm{x}=$ significant influence; 
The linear regression equation $\mathrm{Y}=\mathrm{a}+\mathrm{bX}$, which breast milk volume $=200.995+3.762 \mathrm{X}$.

\subsection{The effect of papaya leaf ethanol extract on $\beta$ - casein $(\operatorname{Csn} 2)$ gene expression}

As shown in Figure 2, the expression level of $\beta$-casein (Csn2) in lactating mice control is 1.01 -fold. The administration of papaya extract increases the level expression of genes to $163.83,530.40$, and 8.13 -fold, on D1, D2, and D3 respectively. The results of the one-way ANOVA test analysis showed that papaya leaf ethanol extract affected the expression level of the $\beta$-casein gene in the three groups $(p=0.000)$. The results of the GamesHowell test analysis showed that the three treatment groups were significantly different from the control group, and the papaya leaf ethanol extract dose of 1.9 $\mathrm{mg} / 200 \mathrm{~g} \mathrm{BW} /$ day produced the highest expression of Csn2 gene expression.

\subsection{The effect of papaya leaf ethanol extract on $\beta$ - casein levels}

Figure 3 presents the analysis of $\beta$-casein levels in the four groups. The $\beta$-casein level in control lactating mice was $60.41 \mu \mathrm{g} / \mathrm{ml}$. The administration of papaya extract increased the protein levels to $70.82,89.9$, and $79.23 \mu \mathrm{g} / \mathrm{ml}$, on D1, D2, and D3, respectively. The oneway ANOVA test results showed a significant difference in the mean $\beta$-casein levels in the four groups $(p<0.000)$. The results of the post hoc test analysis with Tukey's test showed that the dose of $1.9 \mathrm{mg} / 200 \mathrm{~g} \mathrm{BW} /$ day was the highest dose that increased $\beta$-casein levels in lactating rats. Based on the p-value, the administration of D1 did not give a significant difference compared to the control group. Interestingly, the administration of D3 had no significant difference from D1. In contrast, the administration of D2 gave a significant difference compared to the control group $(p<0.05)$.

\subsection{The effect of papaya leaf ethanol extract on total protein levels}

Besides $\beta$-casein, the effect of papaya extract on milk total protein was analyzed. The milk total protein level in control lactating mice was $578.17 \mu \mathrm{g} / \mathrm{ml}$. The administration of papaya extract increased the total protein from breast milk to $745.18,931.15$, and 850.5 $\mu \mathrm{g} / \mathrm{ml}$, on D1, D2, and D3 respectively. The one-way ANOVA test results showed a significant difference in the milk mean total protein content of the four groups of the observation sample $(p<0.000)$. Tukey's test showed that a dose of $1.9 \mathrm{mg} / 200 \mathrm{gr}$ BW/day was the highest dose that increased total protein levels in lactating rats. Figure 4 presents the analysis of the total protein content of the four groups. According to Figure 4, the adminis- tration of D1, D2, and D3 gave significant differences $(p<0.005)$ compared to the control group but the administration of $\mathrm{D} 2$ resulted in the highest total protein levels $(931.15 \mu \mathrm{g} / \mathrm{ml})$.

\section{DISCUSSION}

Breast milk contains protein, carbohydrates, and lipids which are sufficient for the nutrition of babies. Most of these components are synthesized by the alveoli of the mammary glands. The ability of the mammary epithelial cells to produce breast milk is regulated by several factors, such as the hormone system and growth factors, including prolactin, glucocorticoids, and epidermal growth factors?

The mammary epithelial cells localized in the alveoli, synthesize and secrete particularly specific milk proteins in breast milk, including casein which is secreted by the micellar structure of the alveolar mammary epithelial cells, synthesized in the endoplasmic reticulum, and then transferred to the Golgi body for phosphorylation ${ }^{7}$.

The results of this study indicate that papaya leaf ethanol extract has a positive effect on increasing the volume of breastmilk at a concentration of $1.9 \mathrm{mg} /$ $200 \mathrm{~g} \mathrm{BW/day} \mathrm{(Figure} \mathrm{1).} \mathrm{Santana} \mathrm{et} \mathrm{al.} \mathrm{describe} \mathrm{a} \mathrm{study}$ in Europe which states that high glutamate intake can affect glutamate levels in milk, and this is related to high breast milk volume ${ }^{23}$. Glutamate is one of the amino acids found in papaya leaves ${ }^{23}$. The same study was shown by Hosseinzadeh et al. which the water and ethanol extract of Pimpinella anisum L. significantly increased milk production by about $68.1 \%$ and $81 \%$ more than the control group ${ }^{10}$, and so does with fenugreek which can increase milk production ${ }^{32}$. Some of the phytochemical components contained in these plants are alkaloid, flavonoid, and saponin ${ }^{33}$, which in molecular analysis, this type of phytochemical can interact with estrogen receptors so that it can increase milk production ${ }^{34}$. This fact could be attributed that the molecular structure of flavonoids has similarities with the natural estrogen hormone along with other steroid hormone and their antagonist ${ }^{35}$. So it can be used as a potential steroid genesis modulator ${ }^{36}$.

The previous study shows that papaya leaf ethanol extract can increase prolactin level in blood plasma, the prolactin receptor (prlr), the number of lobes and alveoli of mammae epithelial cell in lactating rats ${ }^{37}$. The increasing of prlr in mammary epithelial cells can induce ductal side branching, alveolar budding, and milk secretion through specific transcription factors such as STAT $^{38}$. STAT5 is a transcription factor that is involved in proliferation, differentiation, and survival which can activate by prolactin hormone ${ }^{39}$ through prolactin recep$\operatorname{tor}^{40}$. So that, the presence of prolactin hormone can promote more milk synthesis ${ }^{13}$. 


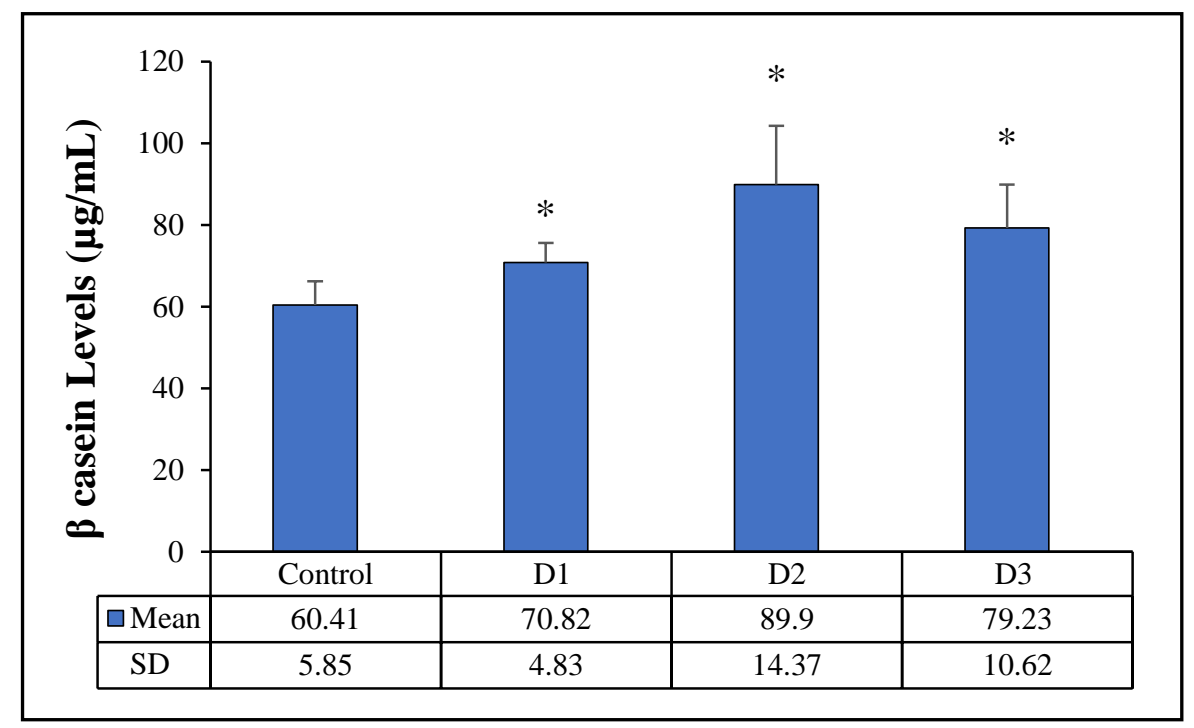

Figure 3. Effect of papaya leaf ethanol extract on $\beta$-casein levels. D1, dose of $0.95 \mathrm{mg} / 200 \mathrm{~g} \mathrm{BW} / \mathrm{day}$; D2, dose of $1.9 \mathrm{mg} / 200 \mathrm{~g}$ BW/day; $\mathrm{D} 3$, dose of $3.8 \mathrm{mg} / 200 \mathrm{~g} \mathrm{BW} /$ day. The data are presented as mean \pm standard deviations. ${ }^{*} p<0.05$ indicated a significant difference in treatment groups compared to the control group based on Tukey's HSD test.

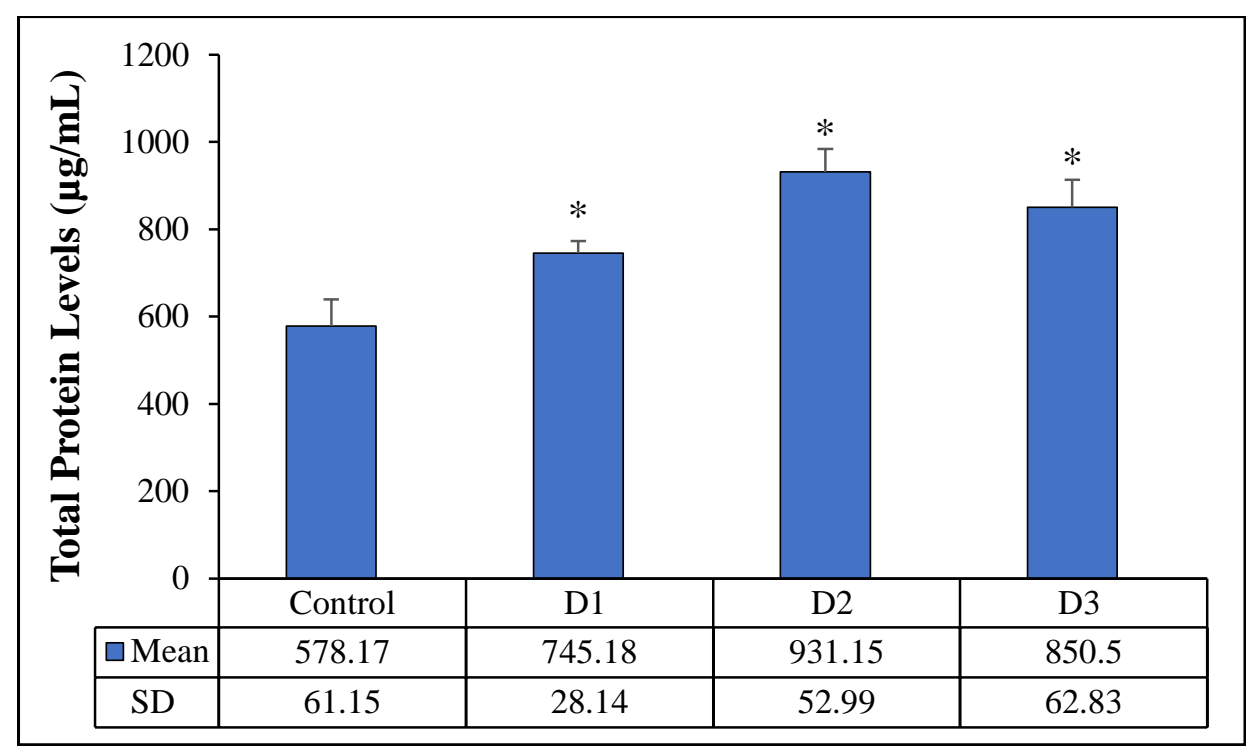

Figure 4. Effect of papaya leaf ethanol extract on the improvement of total protein levels. D1, dose of $0.95 \mathrm{mg} / 200 \mathrm{~g} \mathrm{BW} / \mathrm{day}$; D2, dose of $1.9 \mathrm{mg} / 200 \mathrm{~g} \mathrm{BW} /$ day; D3, dose of $3.8 \mathrm{mg} / 200 \mathrm{~g}$ BW/day. The data are presented as mean \pm standard deviations. * $p<0.05$ indicated a significant difference in treatment groups compared to the control group based on Tukey's HSD test.

The activation of STAT5 also induces the expression of most milk protein genes ${ }^{41}$, and one of the activated genes is $\mathrm{Csn} 2^{42}$. The results of this study indicate that ethanol extract of Carica papaya leaf has a positive effect on increasing the level of $\beta$-casein gene expression with the best concentration of $1.9 \mathrm{mg} / 200 \mathrm{~g}$ BW/day (Figure 2).

Based on the phytochemical analysis, ethanol extract of Carica papaya leaf contains several amino acids, vitamins, and a number of flavonoid compounds (unpublished data), Gao's et al. research shows that the combination of several types of amino acids, namely, histidine, leucine, methionine, and leucine, can increase the $\beta$-casein gene expression in the mammary epithelial glands ${ }^{43}$. The expression of the milk $\beta$-casein gene increased along with the increase in the expression of the amino acid transporter compound gene in the lactation phase. The increase in amino acid transporters is influenced by high levels of amino acids in plasma. Papaya leaves contain amino acids in the form of cysteine, homocysteine, glutamic acid, and phenylalanine ${ }^{44}$. This research is in line with the research of Kim et al. namely that adding cysteine can increase the expression of the $\beta$-casein gene in cows ${ }^{45}$. In another study, Kim et al. also stated that vitamin $C$ in an emulsified state can increase the expression of the $\beta$-casein gene by up to $92 \%{ }^{46}$.

A study by Li et al. showed that $\beta$-casein gene expression can be regulated by acylated ghrelin and unacylated ghrelin in a dose-dependent manner in primary bovine mammary epithelial cells ${ }^{47}$. Ghrelin is an endogenous ligand of the growth hormone secretagogue 
receptor $1 \mathrm{~A}^{48}$, also known as ghrelin receptor, which involves in the stimulation of growth hormone release ${ }^{49}$. Growth hormone acts directly on the mammary epithelial cell in cows to stimulate transcription of major milk protein genes including $\beta$-casein gene, as part of the mechanism to stimulate milk production ${ }^{50}$. Recent studies have mentioned that quercetin, a group of flavonoid compounds, can increase the secretion of growth hormone in rat pituitary cells ${ }^{51}$.

Furthermore, the results of this study indicated that papaya leaf ethanol extract had a positive effect on increasing $\beta$-casein levels with the best concentration of $1.9 \mathrm{mg} / 200 \mathrm{~g} \mathrm{BW} /$ day (Figure 3). Khor et al. showed that the main constituent of papaya leaf extract is flavonoid ${ }^{52}$, where this compound is the main phytochemical component in several types of herbal galactagogues such as Moringa and Foenicullum. Avecedo-Fani et al. stated that the structure of casein micelles can be "assembled" with the addition of quercetin, based on the LCMS/MS analysis, quercetin is one of the flavonoid compounds found in Carica papaya leaf in large amount (unpublished data), so the administration of Carica papaya leaf extract can indirectly involve in increasing $\beta$-casein levels ${ }^{53}$.

Moreover, the papaya leaf ethanol extract has a positive effect on increasing total protein at a concentration of $1.9 \mathrm{mg} / 200 \mathrm{~g} \mathrm{BW} /$ day (Figure 4). Lambert and Edwards stated that the consumption of several types of phytochemicals contained in plants can affect the structure and hormonal properties of vertebrates ${ }^{54}$. Thus, it can affect behavior, physiology, and fecundity. The most identified of these phytochemicals are flavonoids, lignins, and saponins ${ }^{54}$. Carica papaya contains polyphenols which can increase milk protein production ${ }^{27}$, several amino acid components which act as protein precursors ${ }^{21}$, flavonoids and saponins can increase prolactin levels in plasma ${ }^{55}$, and minerals can improve the performance of the membrane transport system ${ }^{21}$. In this study, the increase in $\beta$-casein levels indirectly contributed to the increase in total protein content in milk of lactating rats.

As mentioned before, the increase in $\beta$-casein gene expression is influenced by the increase of growth hormone which induced by ghrelin, through a certain mechanism. It seems that ghrelin activity is stimulated by flavonoid compounds contained in Carica papaya leaves. Nakahara et al. show that ghrelin also plays an important role in the milk production of lactating rats ${ }^{56}$.

Liu et al. showed that the use of herbal galactagogue in lactating rats could increase milk production by regulating the expression and function of aquaporin ${ }^{57}$. Based on the result, it can be seen that D2 $(1.9 \mathrm{mg} /$ $200 \mathrm{~g} \mathrm{BW} /$ day) was an effective dose to increase the milk volume, $\beta$-casein (Csn2) gene expression, $\beta$-casein levels, and total protein levels. Moreover, at D3 there was a decrease in the effect of the extract. This shows that the addition of D3 has caused down regulation in lactating rats, so it does not cause an increase in the milk volume, $\beta$-casein $(\mathrm{Csn} 2)$ gene expression, $\beta$-casein levels, and total protein levels.

Varghese's study showed that prlr internalization is dependent on K63 polyubiquitination of the receptor, whereas elevated PRL signaling would be promote the downregulation of $\mathrm{prll}^{58}$. From the previous study, we know that administration of D3 also causes a decrease of prlr gene expression ${ }^{37}$. Thus, it will indirectly cause a decrese of $\beta$-casein (Csn2) gene expression, then a decrease of $\beta$-casein levels, total protein levels, and milk volume which unknown mechanism.

Since galactagogues have been generally used to increase milk production and total milk protein content $^{59-61}$, Carica papaya can be used as an alternative herbal to increase breast milk production both quality and quantity, but further research is still needed to prove its safety. Further studies are needed to analyze and evaluate the ethanol extract of Carica papaya leaf related to its safety and toxicity. Thus, it is known the appropriate dose of Carica papaya leaf ethanol extract can be absorbed and function optimally in the body.

\section{CONCLUSIONS}

The ethanol extract of Carica papaya leaves can effectively increase milk volume, $\beta$-casein (Csn2) gene expression, $\beta$-casein levels, and total protein levels at a concentration dose of $1.9 \mathrm{mg} / 200 \mathrm{~g} \mathrm{BW} /$ day. In addition, there is a relationship between ethanol extract of Carica papaya leaves and an increase in the volume of breast milk by $3.762 x$ for each addition of one dose of papaya leaf ethanol extract.

\section{ACKNOWLEDGEMENT}

The researcher would like to thank the Central laboratory and Animal Laboratory Universitas Padjadjaran, Bandung, Indonesia for facilitating this research.

\section{Conflict of interest}

All authors declare that there is no conflict of interest in this study.

\section{Funding}

This research was funded by the Ministry of Education through domestic Postgraduate Education scholarships (BPPDN) for doctoral scholarship and research funding assistance from STIKes Dharma Husada Bandung.

\section{Ethics approval}

This research obtained research permission and was approved by the Research Ethics Commission of Universitas Padjadjaran Bandung (no. 1340/UN6.KEP/EC/ 2019). 


\section{Article info:}

Received August 18, 2021

Received in revised form November 12, 2021

Accepted November 12, 2021

\section{REFERENCES}

1. Dror DK, Allen LH. Overview of nutrients in human milk. Adv Nutr. 2018;9:278s-94s.

2. Mosca F, Gianni ML. Human milk: Composition and health benefits. Pediatr Med Chir. 2017;39(2):155.

3. Srinivas R, Eagappan K, Sasikumar S. The effect of naturally formulated galactagogue mix on breast milk production, prolactin level and short-term catch-up of birth weight in the first week of life. Int J Health Sci Res. 2014;4:242-53.

4. Ballard O, Morrow AL. Human milk composition: Nutrients and bioactive factors. Pediatr. Clin North Am. 2013;60(1):49-74.

5. Lacroix M, Bos C, Leonil J, Airinei G, Luengo C, Daré S, et al. Compared with casein or total milk protein, digestion of milk soluble proteins is too rapid to sustain the anabolic postprandial amino acid requirement. Am J Clin Nutr. 2006;84(5):1070-9.

6. Lawrence RA, Lawrence RM. Breastfeeding: A guide for the medical profession. Amsterdam: Elsevier Publisher; 2011.

7. Kobayashi K, Tsugami Y, Matsunaga K, Oyama S, Kuki C, Kumura H. Prolactin and glucocorticoid signaling induces lactation-specific tight junctions concurrent with $\beta$-casein expression in mammary epithelial cells. Biochim Biophys Acta. 2016;1863 (8):2006-16.

8. Zhu J, Dingess KA. The functional power of the human milk proteome. Nutrients. 2019;11(8):1834.

9. Rezaei R, Wu Z, Wou Y, Bazer FW, Wu G. Amino acids and mammary gland development: Nutritional implications for milk production and neonatal growth. J Anim Sci Biotechnol. 2016; 7(1):20.

10. Hosseinzadeh H, Tafaghodi M, Mosavi MJ, Taghiabadi E. Effect of aqueous and ethanolic extracts of Pimpinella anisum L. seeds on milk production in rats. J Acupunct Meridian Stud. 2013;6(1): 18-23.

11. Hill PD, Aldag JC, Demirtas H, Naeem V, Parker NP, Zinaman $\mathrm{MJ}$, et al. Association of serum prolactin and oxytocin with milk production in mothers of preterm and term infants. Biol Res Nurs. 2009;10(4):340-9.

12. Zuppa AA, Sindico P, Orchi C, Carducci C, Cardiello V, Romagnoli C. Safety and efficacy of galactogogues: Substances that induce, maintain and increase breast milk production. $\mathrm{J}$ Pharm Pharm. 2010;13(2):162-74.

13. Tabares PF, Bedoya Jaramillo JV, Ruiz-Cortés ZT. Pharmacological overview of galactogogues. Vet Med Int. 2014;2014: 602894.

14. RM JayadeEpa, Anupama S, Aswathy RM. In silico techniques for the identification of novel natural compounds for secreting human breast milk. Webmedcentral Bioinformatics. 2011;2(8): VMC002120.

15. Alok S, Jain SK, Verma A, Kumar M, Mahor A, Sabharwal M. Plant profile, phytochemistry and pharmacology of Asparagus racemosus (Shatavari): A review. Asian Pac J Trop Dis. 2013; 3(3):242-51.

16. Badgujar SB, Patel VV, Bandivdekar AH. Foeniculum vulgare Mill: A review of its botany, phytochemistry, pharmacology, contemporary application, and toxicology. BioMed Res Int. 2014;2014:842674.

17. Paikra BK, Dhongade HKJ, Gidwani B. Phytochemistry and pharmacology of Moringa oleifera Lam. J Pharmacopuncture. 2017;20(3):194-200.

18. Office of Gene Technology Regulator. The biology of Carica papaya L. (papaya, papaw, paw paw). Australia: Australian Government; 2008.

19. Ikram EHK, Stanley M, Netzel M, Fanning K. Phytochemicals of papaya and its traditional health and culinary uses-A review. J Food Compos Anal. 2015;41:201-11.

20. Parle M, Gurditta. Basketful benefits of papaya. Int Res J Pharm. 2011;2:6-12.

21. Imaga NA, Gbenle GO, Okochi VI, Fanning K. Phytochemical and antioxiandt nutrient constituents of Carica papaya and Parquetina nigrescens extracts. Sci Res Essays. 2010;5:2201-5.

22. Akhila S, Vijayalakshmi NG. Phytochemical studies on Carica papaya leaf juice. Int J Pharm Sci Res. 2015;6:880-3.

23. Santana LF, Inada AC, Espirito Santo BLSd, Filiú WFO, Pott A, Alves FM, et al. Nutraceutical potential of Carica papaya in metabolic syndrome. Nutrients. 2019;11(7):1608.

24. Poole LB. The basics of thiols and cysteines in redox biology and chemistry. Free Radic Biol Med. 2015;80:148-57.

25. van Sadelhoff JHJ, Wiertsema SP, Garssen J, Hogenkamp A. Free amino acids in human milk: A potential role for glutamine and glutamate in the protection against neonatal allergies and infections. Front Immunol. 2020;11:1007.

26. Ennis MA, Rasmussen BF, Lim K, Ball RO, Pencharz PB, Courtney-Martin G, et al. Dietary phenylalanine requirements during early and late gestation in healthy pregnant women. Am J Clin Nutr. 2020;111(2):351-9.

27. Mohanty I, Senapati MR, Jena D, Behera PC. Ethnoveterinary importance of herbal galactogogues-A review. Vet J. 2014;7: 325-30.

28. Sardjono TW, Gondo HK, Nugraha RYB, Putri AT, Effendy MCOS. The use of natural phenomenon in obtaining pregnant Rats and Mice as experimental animals with the same gestational ages. J Trop Life Sci. 2019;9(3):229.

29. Kharisma Y, Ariyoga A, Sastramihardja H. Efek ekstrak air buah pepaya (Carica papaya L.) muda terhadap gambaran histologi kelenjar mamma mencit laktasi. Majalah Kedokteran Bandung. 2011;43:160-5.

30. Zhang QW, Lin LG, Ye WC. Techniques for extraction and isolation of natural products: A comprehensive review. Chin Med. 2018;13:1-26.

31. George D, Mallery P. IBM SPSS statistics 25 step by step: A simple guide and reference. $5^{\text {th }}$ ed. New York: Routledge; 2019.

32. Sevrin T, Alexandre-Gouabau MC, Castellano B, Aguesse A, Ouguerram K, Ngyuen P, et al. Impact of fenugreek on milk production in rodent models of lactation challenge. Nutrients. 2019;11(11):2571.

33. Alqethami A, Aldhebiani AY. Medicinal plants used in Jeddah, Saudi Arabia: Phytochemical screening. Saudi J Biol Sci. 2021; 28(1):805-12.

34. Powers CN, Setzer WN. A molecular docking study of phytochemical estrogen mimics from dietary herbal supplements. In Silico Pharmacol. 2015;3:4.

35. Li M, Hassan FU, Tang Z, Peng L, Liang X, Li L, et al. Mulberry leaf flavonoids improve milk production, antioxidant, and metabolic status of water buffaloes. Front Vet Sci. 2020;7:599.

36. Panche AN, Diwan AD, Chandra SR. Flavonoids: An overview. J Nutr Sci. 2016;5:e47.

37. Herawati Y, Kalsum U, Arsana Wiyasa IW, Yuniarti L, Wahju Sardjono T. Ethanol extract of Carica papaya leaf can increase breast milk in lactating rat. Open Access Maced J Med Sci. 2021; 9(A):520-6.

38. Gorvin CM. The prolactin receptor: Diverse and emerging roles in pathophysiology. J Clin Transl Endocrinol. 2015;2(3):85-91.

39. Gómez-Gallego C, Ilo, Jaakkola U, Salminen S, Periago MJ, Ros $\mathrm{G}$, et al. A method to collect high volumes of milk from mice (Mus musculus). An Vet (Murcia). 2014;29:55-61.

40. Miyoshi K, Shillingford JM, Smith GH, Grimm SL, Wagner $\mathrm{KU}$, Oka T, et al. Signal transducer and activator of transcription (Stat) 5 controls the proliferation and differentiation of mammary alveolar epithelium. J Cell Biol. 2001;155(4):531-42.

41. Anderson SM, Rudolph MC, McManaman JL, Neville MC. Key stages in mammary gland development. Secretory activation in the mammary gland: It's not just about milk protein synthesis!. 
BCR. 2007;9(1):204.

42. Schmitt-Ney M, Doppler W, Ball RK, Groner B. Beta-casein gene promoter activity is regulated by the hormone-mediated relief of transcriptional repression and a mammary-gland-specific nuclear factor. Mol Cell Biol. 1991;11(7):3745-55.

43. Gao HN, Zao SG, Zheng N, Zhang YD, Wang SS, Zhou XQ, et al. Combination of histidine, lysine, methionine, and leucine promotes $\beta$-casein synthesis via the mechanistic target of rapamycin signaling pathway in bovine mammary epithelial cells. J Dairy Sci. 2017;100(9):7696-709.

44. Chen F, Zhang S, Deng Z, Zhou Q, Cheng L, Kim SW, et al. Regulation of amino acid transporters in the mammary gland from late pregnancy to peak lactation in the sow. J Anim Sci Biotechnol. 2018;9:35.

45. Kim TI, Kim TG, Lim DH, Kim SB, Park SM, Lim HJ, et al. The effect of nanoemulsified methionine and cysteine on the in vitro expression of casein in bovine mammary epithelial cells. Asian-Australas J Anim Sci. 2019;32(2):257-64.

46. Kim TI, Kim TG, Lim DH, Kim SB, Park SM, Hur TY, et al., Preparation of nanoemulsions of vitamin $\mathrm{A}$ and $\mathrm{C}$ by microfluidization: Efficacy on the expression pattern of milk-specific proteins in MAC-T cells. Molecules. 2019;24(14):2566.

47. Li S, Liu J, Lv Q, Zhang C, Xu S, Yang D, et al. AG and UAG induce $\beta$-casein expression via activation of ERK1/2 and AKT pathways. J Mol Endocrinol. 2016;56(3):213-25.

48. Müller TD, Nogueiras R, Andermann ML, Andrews ZB, Anker SD, Argente J, et al. Ghrelin. Mol Metab. 2015;4(6):437-60.

49. Yin Y, Li Y, Zhang W. The growth hormone secretagogue receptor: Its intracellular signaling and regulation. Int J Mol Sci. 2014;15(3):4837-55.

50. Zhou Y, Akers RM, Jiang H. Growth hormone can induce expression of four major milk protein genes in transfected MAC-T cells. J Dairy Sci. 2008;91(1):100-8.

51. Lin YC, Wu CJ, Kuo PC, Chen WY, Tzen JTC. Quercetin 3-Omalonylglucoside in the leaves of mulberry (Morus alba) is a functional analog of ghrelin. J Food Biochem. 2020;44(9):e13379.

52. Khor BK, Chear NJY, Azizi J, Khaw KY. Chemical composition, antioxidant and cytoprotective potentials of Carica papaya leaf extracts: A comparison of supercritical fluid and conventional extraction methods. Molecules. 2021;26(5):1489.

53. Acevedo-Fani A, Dave A, Singh H. Nature-assembled structures for delivery of bioactive compounds and their potential in functional foods. Front Chem. 2020;8:564021.

54. Lambert MR, Edwards TM. Hormonally active phytochemicals and vertebrate evolution. Evol Appl. 2017;10(5):419-32.

55. Bzikowska-Jura A, Czerwonogrodzka A, Oledzka G, SzostakWęgierek D, Weker H, Wesołowska A. Maternal nutrition and body composition during breastfeeding: Association with human milk composition. Nutrients. 2018;10:1294.

56. Nakahara K, Hayashida T, Nakazato M, Kojima M, Hosoda H, Kangawa $\mathrm{K}$ et al. Effect of chronic treatments with ghrelin on milk secretion in lactating rats. Biochem Biophys Res Commun. 2003;303(3):751-5.

57. Liu F, Pawliwec A, Feng Z, Yasruel Z, Lebrun JJ, Ali S. Prolactin/ Jak2 directs apical/basal polarization and luminal linage maturation of mammary epithelial cells through regulation of the Erk1/2 pathway. Stem Cell Res. 2015;15(2):376-83.

58. Varghese B. Mechanisms of the downregulation of prolactin receptor and their role in cell proliferation Ph.D. [dissertation]. Pennsylvania, United States: University of Pennsylvania; 2010.

59. Bazzano AN, Hofer R, Thibeau S, Gillispie V, Jacobs M, Theall KP. A review of herbal and pharmaceutical galactagogues for breast-feeding. Ochsner J. 2016;16(4):511-24.

60. Turkyılmaz C, Onal E, Hirfanoglu IM, Turan O, Koç E, Ergenekon $\mathrm{E}$, et al. The effect of galactagogue herbal tea on breast milk production and short-term catch-up of birth weight in the first week of life. J Altern Complement Med. 2011;17(2):139-42.

61. Damanik R, Wahlqvist ML, Wattanapenpaiboon N. Lactagogue effects of Torbangun, a Bataknese traditional cuisine. Asia Pac J Clin Nutr. 2006;15(2):267-74. 